\title{
Satisfaction Confirmatory Factor Analysis of Tourists toward Eco-Friendly Hotel Business in Central Region of Thailand
}

\author{
Sanhakot Vithayaporn ${ }^{1 *}$, Rajit Khongharn ${ }^{2}$ \\ ${ }^{I}$ School of Business Administration Sripatum University, Thailand \\ ${ }^{2}$ Faculty of Management Sciences, Panyapiwat Institute of Management, Bangkok, Thailand
}

*Corresponding Author: Sanhakot Vithayaporn, School of Business Administration Sripatum University, Thailand

\begin{abstract}
This research has studied on tourist satisfaction confirmatory factor analysis toward eco-friendly hotel business. The objective is studying variable set which utilizes for main factor in causal factor analysis of European Customer Satisfaction Index (ECSI) model. Questionnaire is used to collect data from tourist sample group of 400 persons who use services at eco-friendly hotel in major attraction cities in central region of Thailand while Frequency, Percentage, Means, Standard Deviation, Pearson's Correlation Analysis, and Confirmatory Factor Analysis were utilized in data analysis. Result of data analysis found that Chi-Square $\left(X^{2}\right)$ equals to 1272.62 which has statistical significance at the level of $p$-value $=0.53$, relative Chi-Square $\left(X^{2} / d f\right)=1.74$, Comparative Fit Index $(C F I)=0.96$, Goodness of Fit Index $(G F I)=0.95$, Adjust Goodness of Fit Index $(A G F I)=0.95$ and Root Mean Square Error of Approximation $(R M S E A)=0.013$, all of them passed the criteria. In addition, the analysis result of customer satisfaction index in eco-friendly hotel business found that entrepreneur should give priority to customer expectation and follow by satisfaction and perception on product quality respectively.
\end{abstract}

Keywords: Satisfaction, Eco-friendly, ECSI

\section{INTRODUCTION}

Tourism is an industry with high expansion; it takes important role toward economic and social system in Thailand. Major revenue from tourism can bring in foreign currency, generate employment as well as expand the prosperity to the region. Moreover, tourism is important for infrastructure development in terms of transportation including trade and investment (Ministry of Tourism and Sports, Thailand, 2017). However, the proportion of tourist behavior has been increased for outbound long distance which approximates to 24\%. They are interested in and prioritize more on ecological, cultural, community and medical tourism. Therefore, tourism activity and service should emphasize on tourist group who is interested in specific activity and service related to the nature and environment (Pitsanu Chuengsamor, 2000).

Currently more than $80 \%$ of tourists in all ages and genders are interested in eco-friendly product or service, then green market tends to be main stream for business operation (Jirawat Anuwitchanon et al., 2011). In order to meet business requirement, business operation should make tourists to feel that they can participate in environmental care. There are many studies and researches that seek for development method for sustainable attractions. From Lonely Planet study in 2007 indicated that $88 \%$ of tourists have focused on sustainable tourism (Shugg et al., 2007, p.127).

Therefore, tourism activity of tourists nowaday is part of taking care, protecting the environment and using accommodation service in the attractions. It becomes an "expectation" of consumer in accommodation business (Foster, et al., 2000). In terms of accommodations service, it has environmental conservation role for eco-friendlier concept, increasing environmental regulation at all levels, concerning about business ethics and conducting business in terms of social responsibility, Tinsley, s (2001).

Business entrepreneurs use eco-friendly policy which causes direct and indirect benefits for their businesses by using environmental conservation policy to apply to such service. It must consider for 
understanding and satisfaction which lead to customer loyalty, then it will meet entrepreneur objective in environmental care policy and long term business achievement. On the other hand, if service management policy of entrepreneurs is not acceptable to the tourists, it will cause any loss. Instrument used to track customer satisfaction in order to receive customer feedback on performance and service is National Customer Satisfaction Index (NCSI) model which considered as leading indicator. It can reflect trend of business performance or future competitiveness. In developed countries have different index criteria as appropriate, namely American Customer Satisfaction Index: ACSI, European Customer Satisfaction Index: ECSI where such satisfaction index models are similar to each other. This research will study in accordance with business framework which has eco-friendly policy by managing relationship with customer satisfaction factor according to European Customer Satisfaction Index (ECSI) model and satisfaction confirmatory factor analysis of tourists toward hotel business which uses eco-friendly policy.

\section{A REVIEW OF THE RELATED LITERATURE}

A researcher on consumer behavior and marketing of developed countries has initiated consumer satisfaction index which has been commenced on 1970 onwards by studying to cover customer satisfaction. In 1989 Fornell et al. from Michigan University have developed customer satisfaction model to be national satisfaction instrument for Sweden for the first time. (Fornell, 1992) Fundamental models for these index evaluations are structural equation model that connect customer satisfaction to other factors, namely perception on customer expectation quality and value perception that lead to customer loyalty and complaint (Ronald Van Haaften, 2017).

ECSI (European Customer Satisfaction Index) is customer satisfaction index in Europe where countries among the first that achieved indexing are United States and Sweden. Especially Sweden has encouraged European Commission to support the creation of customer satisfaction index in European Union which started conducting satisfaction index in 10 countries of European Union in 1999. At first ECSI has equation structure that related to variable where customer satisfaction will have an affect on customer loyalty and has been indexed by image perception at the same time. They are the process of cognitive, opinion, feeling, belief and impression that arising from an integration of knowledge and experience together. Image characteristic causes perception and something appears and then links up in mind, it generates memorability and feeling for each individual that is difficult to fade away. Customer expection is something that each individual will anticipate or expect from something by consider the actual possibility. Each individual expectation may be different due to experiences in the past, expectation level, value perception and quality perception. Quality perception divided into hardware and software, namely latent service in an interaction which a purchaser receives from a seller or separating seller service from products which include personal behavior of a seller and selling environment. Details in seven variables consist of two to five index variables which will be used in questionnaire to take customer survey and collect data for evaluation (Kristensen, Martensen, \& Gronholdt, 1999). Details of European satisfaction index model are in Figure 1.

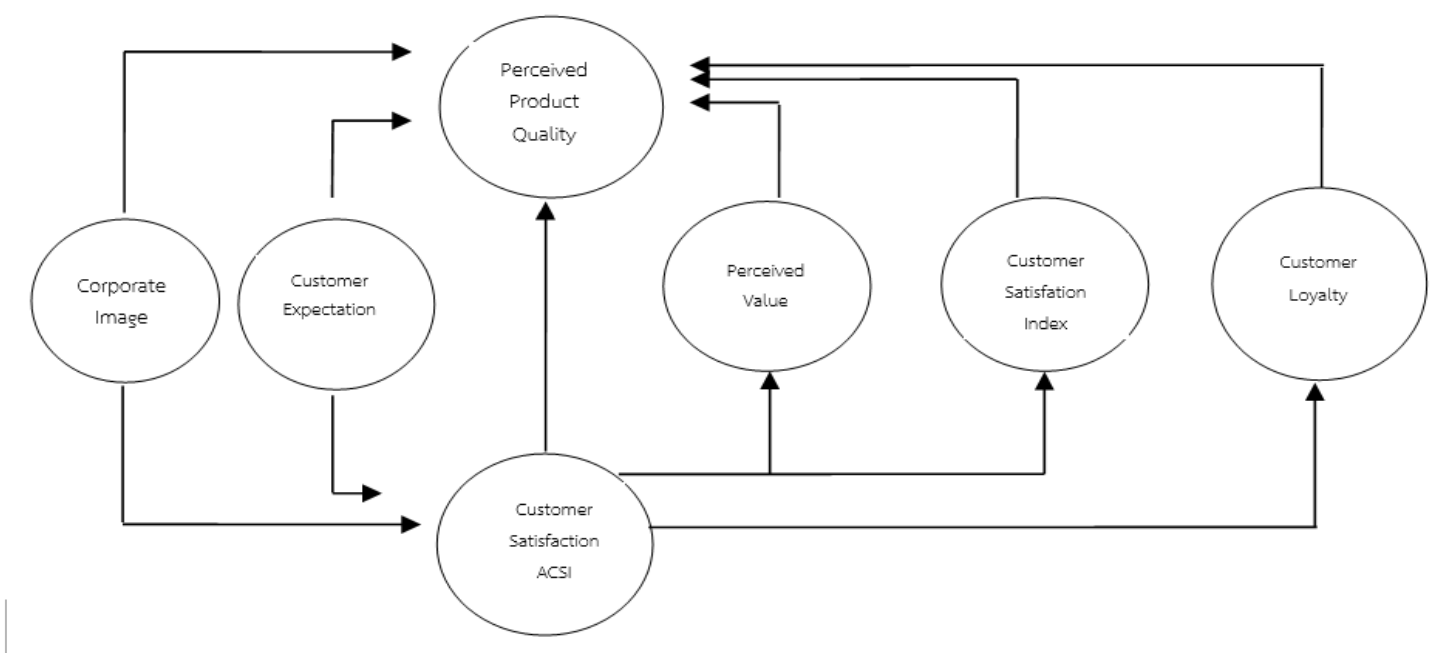

Figure1: The European Customer Satisfaction Index model, Source: Ronald Van Haaften, 2017 
Sharma and Hardeep Chahal (2006) have analyzed the relationship between social responsibility and marketing performance and found that CSR Image of an organization (CSR Image) has been determined from relationship level in an organization, economic value from an operation and social activities. Such CSR image has positive relationship with Brand Equity and Competitive Advantage.

Longinos et al. (2009) has studied unique and remarkable role of social activity in an organization which effect to consumer loyalty. In case study of banking industry found that CSR has indirect influence on consumer loyalty via variable of company evaluation, $\mathrm{T} 1$ identity attractiveness and C-C Identification where an influence on T1 C-C Identification toward consumer loyalty will be high on the condition that Identity Salience is high.

Gronroos. (1988) found that image is the factor that effects satisfaction and customer loyalty significantly. Image of budget hotel can be divided into 2 parts, the first part is tangible, especially hotel physical description which covers location, decoration including cleanliness and the second part is abstract which covers perception and inner feeling of customer, namely hotel brand reliability and customer confidence toward such brand. Both factors will enhance the hotel image.

Heskett. (1997) has studied employee quality and indicated the relationship between employee who provides service and customer. Responsibility, satisfaction and loyalty of employee have an influence on customer perception in terms of product value and service and it directly effects to satisfaction and loyalty of customer.

Krittiya Chongrueangsup (2010) has studied the expectation and perception on service quality that related to brand image of Seven Eleven in Bangkok by studying for expectation level and perception toward service quality of Seven Eleven customer, then compared such expectation and perception on service quality. She also studied demography of customers who have an affect on Seven Eleven brand image including the level of service quality that related to its brand image. It found that there is statistical significance in the difference between expectation and perception. For its image found that Seven Eleven customers who are different in demography, monthly average income and service frequency have different opinions toward Seven Eleven image. In addition, the result also indicates that expectation, quality perception and service in all aspects are related to Seven Eleven images.

Kholthanasep, G. (2001) has studied for expectation and service quality perception of customer toward first class hotel in Bangkok with the purpose to study the difference between customer expectation and service quality perception that received from hotel service. The result found that hotel customer has expectation toward service quality factor which can be categorized by its priority as follows: Reliability, Empathy, Assurance, Tangible and Responsiveness. Service quality perception of customer can be categorized by its priority as follows: Reliability, Empathy, Tangible, Responsive and Assurance. Comparison results between expectation and service quality perception found that customer expectation is different from perception of actual hotel service quality. It also found that different age and using purpose have different expectation toward hotel service quality.

Choi \& Chu (2000) found that quality of hotel room which consists of pillows and mattress softness, appropriate temperature and tranquility in the room are all factors that have an affect on positive attitude of customers. As customer has positive perception to room quality, he will give compliment which is satisfaction, on the other hand, if customer has negative perception he will complain. In addition, this study also compares the requirement between Eastern and Western customer and found that Western customer gives priority to hotel room quality while Eastern customer gives priority to the price. Therefore, customers in different culture also determine their requirement. Then product and service of hotel especially inside the room should consist of physical characteristics where customers can perceive and touch even the room size.

Low, Lee \& Cheng (2013) has studied the relationship between satisfaction and price in retail industry in Taiwan and the result found that perceived value in term of price has positive influence on customer satisfaction.

Chinomona, Richard, Okoumba \& Pooe (2013) has studied the impact of product quality toward pricing perception. It has an affect on student confidence and intention to buy electronic devices. Result of this research found that perceived value in term of price has positive influence on customer confidence. 
Ok, Back, \& Shanklin (2005): When customer satisfies with product and service, it highly causes them to repeat order which means he will purchase such product and service repeatedly where its work meets the desired characteristics. However, the desired characteristics of product and service may not always cause satisfaction.

Ostrom \& Iacobucci (1995): When customer satisfies with product and service, he will repeat order and pass along such product and service. If such product and service have lower quality than expected, he will not satisfy and will change to use competitor product.

Taylor; Celuch; \& Goodwin (2004) have studied customer loyalty toward significant brand value of industrial customer in two groups which are a group of industrial tools and a group of heavy tools. The study found that loyalty in product brand derives from six factors which are Satisfaction, Value, Resistance to Change, Affect, Trust and Brand Equity.

Reichheld, et al. (1990) said that satisfied customer tends to pass along the product or service that they can perceive and has possibility to recommend. It indicates customer perception.

Qingqing, et al. (2014) has studied service quality and satisfaction in fast food restaurant of Chinese customer by collecting data from 205 persons and using structural equation model analysis to test the hypothesis. The result found that service quality has positive influence on satisfaction.

Summary of a review of the related literature from processing knowledge of variable relationship in satisfaction index with ECSI are as follows:

Table1: Processing summary of a review of the related literature and variable relationship of index

\begin{tabular}{|c|c|}
\hline Variable relationship & Reference research \\
\hline H1: Image creation toward customer loyalty & $\begin{array}{l}\text { Longinos et al. (2009 } \\
\text { (Grönroos, 2000) และ (Kristensen, et al., 1999) }\end{array}$ \\
\hline \multicolumn{2}{|c|}{$\begin{array}{l}\text { H2: Perception on service quality has influence on Krittiya Chongruangsap. (2010) } \\
\text { satisfaction }\end{array}$} \\
\hline \multicolumn{2}{|c|}{$\begin{array}{l}\text { H3: Perception on product quality has influence on (Heskett, 1997) } \\
\text { value perception }\end{array}$} \\
\hline H4: Satisfaction has influence on loyalty & (Ok, Back, \&Shanklin, 2007) (Ostrom\&Iacobucci, 1995 \\
\hline H5: Expectation has influence on image & Krittiya Chongruangsap. (2010) \\
\hline \multicolumn{2}{|c|}{$\begin{array}{l}\text { H6: Expectation has influence on product and service Gaysorn Kholthanasep (2544) } \\
\text { quality }\end{array}$} \\
\hline \multicolumn{2}{|c|}{$\begin{array}{l}\begin{array}{l}\text { H7: Perception on product quality has influence on Choi \& Chu (2000) } \\
\text { satisfaction } \\
\text { Low, Lee \& Cheng (2013) }\end{array} \\
\end{array}$} \\
\hline H8: Image has influence on satisfaction & (Grönroos, 2000) และ (Kristensen, et al., 1999) \\
\hline H9: Value perception has influence on loyalty & Taylor; Celuch; \& Goodwin. (2004) \\
\hline H10: Image has influence on value perception & Hardeep and Sharma (2006) \\
\hline $\begin{array}{l}\text { H11: Satisfaction has influence on perce } \\
\text { product value }\end{array}$ & 9 \\
\hline
\end{tabular}

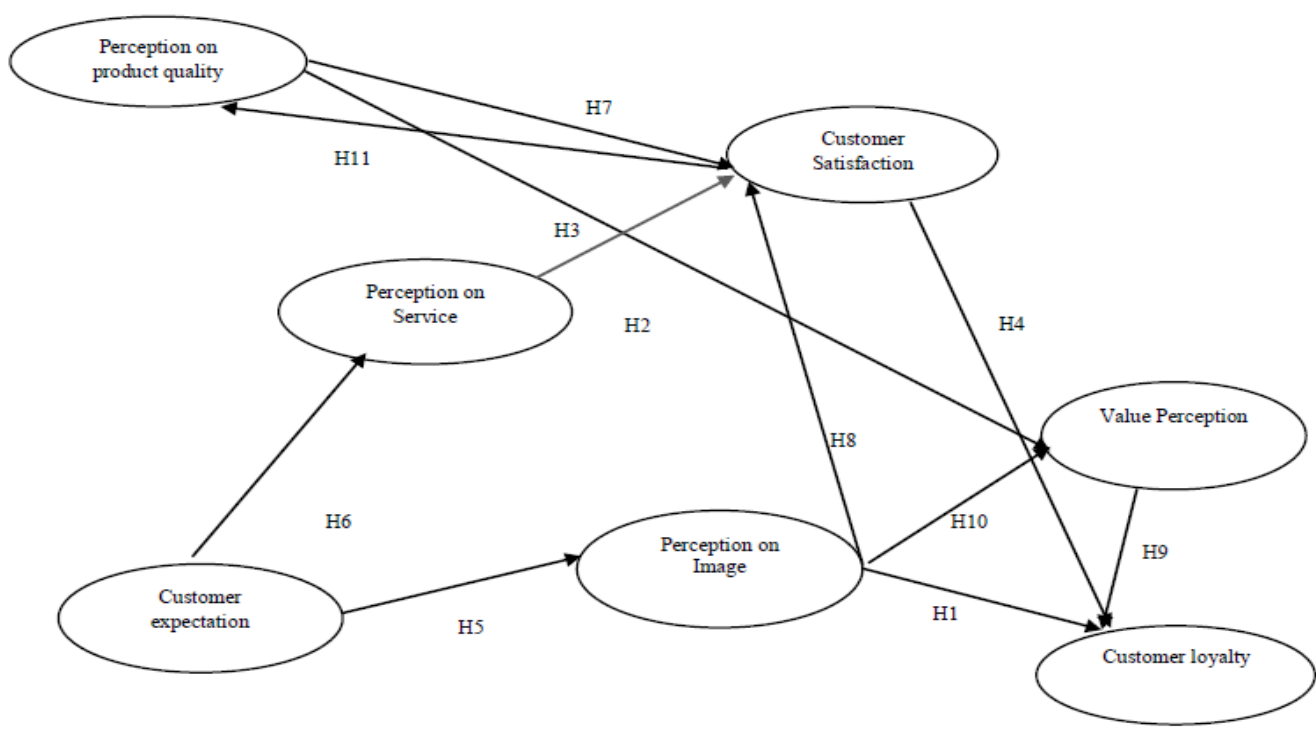

Figure2: shows the conceptual model of the research 


\section{RESEARCH METHODOLOGY}

The research population consists of tourist who is eco-friendly hotel customer. A researcher has considered for research description of sample group; it needs to use advance analysis statistics which is Confirm Factor Analysis. Therefore, sample size has been determined to correspond with preliminary use of statistics. It needs a large sample group as criteria for size determination which has approximate to $10-20$ persons per 1 sample parameters (Hair, Black, Babin\& Anderson, 2010, pp.100-102). This sample group is eco-friendly hotel customers and has 40 variables, then this research will use 400 sample groups. Random sampling in this research uses Purposive sampling (Wannee Kamkate, 2008, page 221) and a researcher uses close end questionnaires as an instrument to collect data. Questionnaire divided into 2 parts; Part 1-General information of a respondent which is check list question and Part 2- Questionnaires to determine an opinion according to Rating Scale of Likert. Each item divided into 5 levels which an instrument quality has been tested and analyzed for reliability test. This research uses 30 sample groups with Cronbach's Alphas Coefficient. It has confidence equals to 0.845 which is more than 0.7, then it indicates that an instrument has high and acceptable confidence (Chamaiporn Kanchanakitsakul, 2012).

\section{DATA ANALYSIS AND STATISTICS USED IN THIS RESEARCH}

Descriptive Statistics used in this analysis which consists of Frequency, Percentage, Mean and Standard Deviation. The analysis examines the consistency between model and empirical material, namely Chi-Square which is statistical hypothesis testing and its consistent function is zero. If ChiSquare is extremely low or closes to zero, it indicates that LISREL model is consistent with empirical material (Jöreskog\&Sörbom. 1993: 122; Diamantopoulos \&Siguaw. 2000: 83). Chi-Square testing can be tested in two ways: 1) p-value, if p-value is more than 0.05, it indicates that LISREL model is consistent with empirical material as it shows that data of LISREL model is insignificantly different from empirical material, 2) time of Chi-Square per degree of freedom, if Chi-Square is less than 3 times of degree of freedom (Hair; et al. 2010: 668) it considered that LISREL model data is consistent with empirical material and Root Mean Square Error of Approximation (RMSEA) indicates an inconsistence between created model and covariance matrix of population which Browne and Cudeck (Browne; \&Cudeck. 1993: 144) have explained that if RMSEA is less than .05, it indicates that it has close fit.

\subsection{Hypotheses Testing}

Satisfaction confirmatory factor model of tourist toward eco-friendly hotel business that developed has consistency with empirical material.

\section{RESOURCE}

Most of sample group who respond the questionnaire in this research spend 2 nights at the hotel for second time. Type of accommodation is Superior Room and rate is 3,001-4,000 Baht. Objective of most people are relaxation. Room reservation method is making a reservation via hotel website. How many times do they stay at the hotel? They stay for 1-5 times per year. Type of hotel that choose to stay the most is Chain hotel such as Le Meridien, Sheraton, Hilton, Conrad, Ramada, Centara, Novotel, Sofitel, ibis, Marriott, Ritz Carlton, Radisson, Hyatt, Dusit etc. and the level will be five stars' hotel.

\subsection{Study Result on Opinions According to Eco-Friendly Policy by using ECSI Model}

Causal factor in terms of image and social responsibility of the hotel are in maximum level while unique and distinguish service which are different from other hotels including hotel reliability is ISO 14001, ECO-label, Green globe 21, Green life and Eco product will be in secondary level. Customer expectation found that the most expectation is eco-friendly products and modern facility will be the second. When hotel uses eco-friendly policy, customer will have expectation from its presented products, then he can realize the applied policy. Customers will be confident and be able to cooperate with hotel project under such policy. Perception on service quality found that customer will consider inside accommodation whether it has modern and convenient facilities to use such as coffee machine or wireless internet etc. Value perception found that customer will consider value perception from worthiness and received value when comparing between service charge and service value. Customer 
satisfaction found that customer satisfies with hotel location, environment management and service charge. Customer complaints found that customer will consider for the complaints from a hotel that wish to stay. If hotel has environmental complaints, it effects the decision to stay and complaints in the past have influence on the decision as well. In addition, customer loyalty found that customer will recommend his acquaintance to stay at the hotel. If he has opportunity he will come back to this hotel, then customer thinks that he has loyalty to that hotel.

\subsection{Result of the First Confirmatory Factor Analysis of Satisfaction Index of Eco-Friendly Hotel Customer}

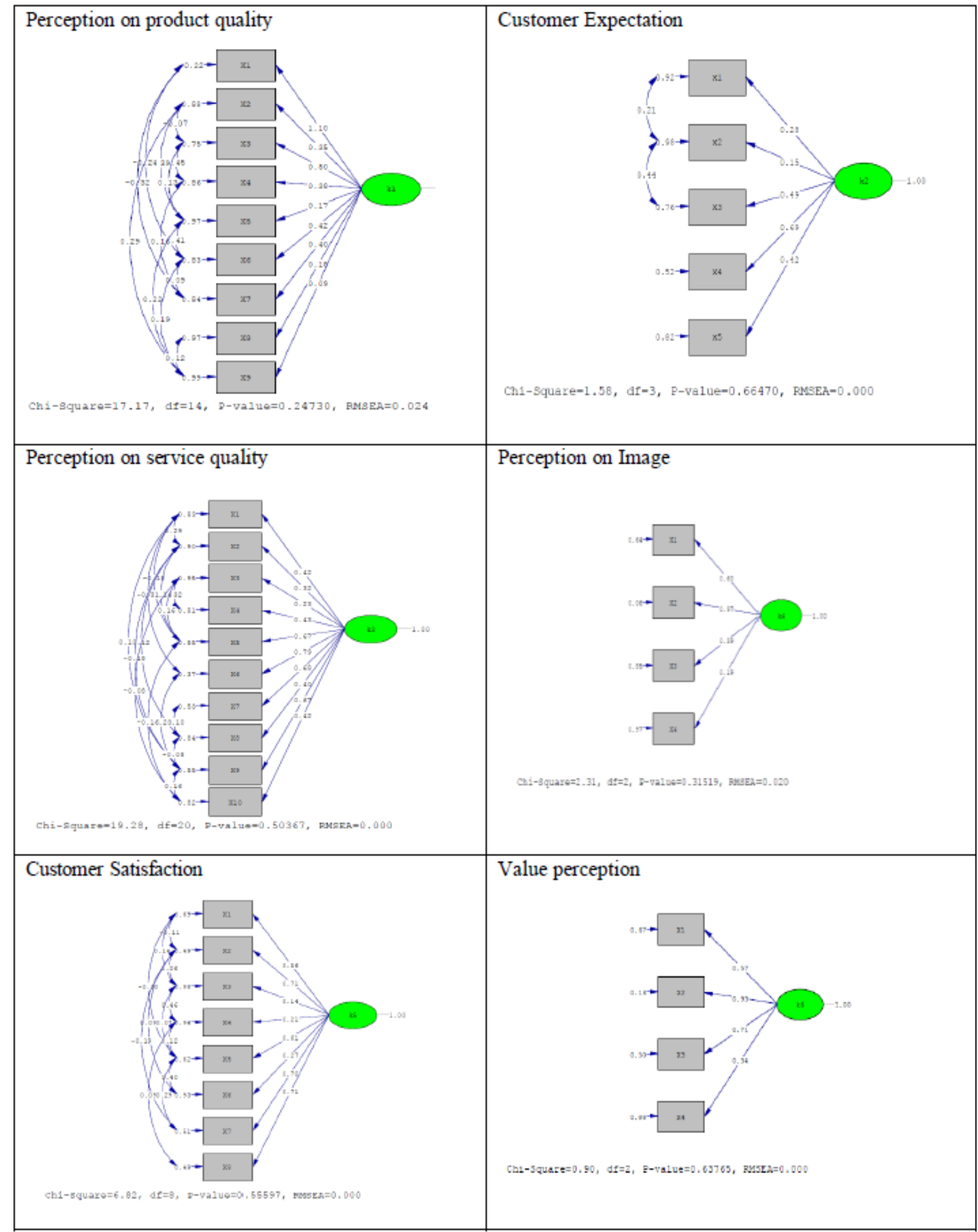

Figure3: The first confirmatory factor analysis of satisfaction index of eco-friendly hotel customer, The second confirmatory factor analysis of satisfaction index of eco-friendly hotel customer 


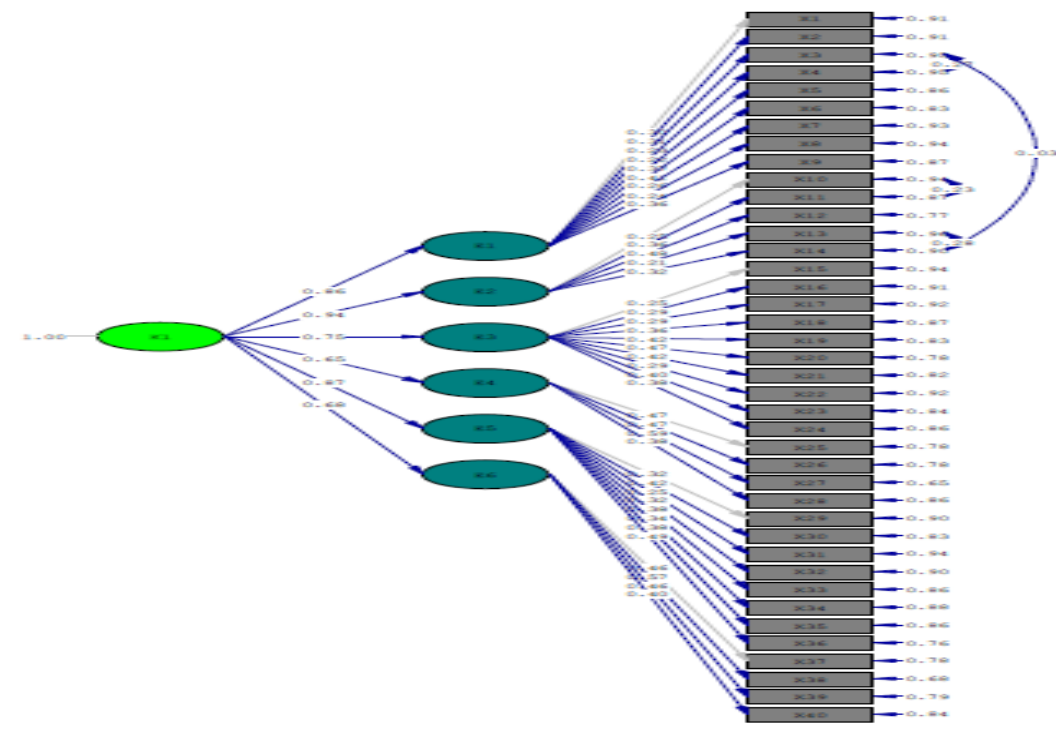

Figure4: The second confirmatory factor analysis of satisfaction index of eco-friendly hotel customer

Chi-Square $=1272.62, \mathrm{df}=730, \mathrm{P} 3$ value $=0.53427, \mathrm{RMSEA}=0.013$

Table2: Result of the second confirmatory factor analysis of satisfaction index of eco-friendly hotel customer

\begin{tabular}{|l|l|l|l|}
\hline \multicolumn{1}{|c|}{ Items } & \multicolumn{1}{c|}{ Criteria } & Calculated Value & \multicolumn{1}{c|}{ Result } \\
\hline $\mathrm{X}^{2}$ & No statistical significance at level of .05 & 1272.62 & - \\
\hline $\mathrm{Df}$ & - & 730 & - \\
\hline $\mathrm{p}$-value & $\mathrm{P}>0.05$ & 0.53 & - \\
\hline $\mathrm{X}^{2} / \mathrm{df}$ & $\mathrm{X}^{2} / \mathrm{df}<2$ & 1.74 & pass the criteria \\
\hline CFI & close to 1.0 & 0.96 & pass the criteria \\
\hline GFI & close to 1.0 & 0.95 & pass the criteria \\
\hline AGFI & close to 1.0 & 0.95 & pass the criteria \\
\hline RMSEA & close to 0.0 & 0.01 & pass the criteria \\
\hline
\end{tabular}

Result of data analysis found that Chi-Square $\left(\mathrm{X}^{2}\right)$ equals to 1272.62 which has statistical significance at level of $\mathrm{p}$-value $=0.53$, Relative Chi-Square $\left(\mathrm{X}^{2} / \mathrm{df}\right)=1.74$, Comparative Fit Index $(\mathrm{CFI})=0.96$, Goodness of Fit Index $(\mathrm{GFI})=0.95$, Adjust Goodness of Fit Index (AGFI) $=0.95$ and Root Mean Square Error of Approximation $(\mathrm{RMSEA})=0.013$, all of them passed the criteria.

The result of satisfaction index analysis of tourists toward eco-friendly hotel found that tourists who stay at the hotel give priority to customer expectation and follow by satisfaction and perception on product quality respectively.

\section{Conclusion}

The study result by using ECSI from tourists who stay at eco-friendly hotel found that tourists have considered image perception which has overall maximum influence toward customer loyalty, then follow by customer expectation, value perception and satisfaction respectively. It is consistent with a research of Gronroos (1988) which found that image is the factor that has significant affect on satisfaction and customer loyalty. Hotel image can be divided into 2 parts: the first part is tangible; especially hotel physical description which covers location, decoration including cleanliness and the second part is abstract which covers perception and inner feeling of customer, namely hotel brand reliability and customer confidence toward such brand. Both factors will enhance the hotel image.

From confirmatory factor analysis of satisfaction index of tourist toward eco-friendly hotel which is the final result found that model is consistent with empirical material in statistical significance. It can confirm that significant factors that tourists satisfy with eco-friendly hotel have 3 significant components. Each of them has key factors as follows: (1) Customer expectation, the products used in the hotel should be clearly associated with eco-friendly policy which is consistent with Krittiya Chongrueangsup (2010) that an expectation and perception on service quality are related to the image. Customers in different demography also have different opinions toward the image. In addition, expectations, perception on service quality in all aspects are related to various aspects of image. (2) 
Satisfaction in terms of hotel service is satisfied as expected. Customer also satisfies with service charge and environment management within the hotel which is consistent with a research of Reichheld, et al. (1990). This research found that when customer satisfies with the hotel, he will pass along the value of product or service that they perceived and has possibility to recommend it. It indicates the customer perception. (3) Perception on product quality by acknowledging environment development and being a hotel member to protect an environment is consistent with Kholthanasep, G. (2001). It found that hotel customer has expected from the factor of product quality and service as follows: Reliability, Empathy, Assurance, Tangible and Responsiveness. Therefore, causal factor of tourist satisfaction index model which caused from European Customer Satisfaction Index (ECSI) in eco-friendly hotel can be a guideline for eco-friendly hotel entrepreneurs to take benefits from the result of tourist satisfaction index analysis in order to apply for their marketing direction. Then it will cause satisfaction and lead to loyalty in hotel product and service. Finally, it can generate more marketing value.

\section{REFERENCES}

[1] Krittiya Chongruangsap. (2010) Expectations and perceptions of service quality related to the image of 7Eleven stores in Bangkok. Master's thesis, Burapha University.

[2] Department of Tourism. (2017). From http://www.mots.go.th/main.php?filename=index Search in 3 March 2017

[3] Chirawat Anuwatananont et al. (2011) Development of environmental services.

[4] Hotel / Green Accommodation Koh Samet, Rayong, Thailand Suan Dusit Rajabhat University. [in Thai]

[5] Natthaphon Assarat (2008) Measurement of Eco-friendly Consumption Behavior: Survey Research Journal of Chulalongkorn Business Review 30,117-118 (Jul-Dec) 145-156.

[6] Treetip Boonyam 2011 Green tourism for the world sustainability and the guidelines For entrepreneurs Executive Journal 31.2 (Apr-Jun 2011) 184-189. ISSN 0125-

[7] Pitsanu Cheagsmor (2000) Sustainable Resource Management Approach: A Case Study of LamTa Klong River, Nakhon Ratchasima Province Master Thesis (from: the Graduate School of Krirk University

[8] Choi, Tat Y and Raymond Chu, (2000)" Levels of satisfaction among Asian and Western travellers", International Journal of Quality \& Reliability Management, Vol.17 Issue: 2, pp.116-132,

[9] Fornell, Claes. (1992). A national customer satisfaction barometer: The Swedish experience. Journal of Marketing, 56, pp. 6-21.

[10] Foster, S.T., Sampson, S.E. and Dunn, S. (2000) the impact of customer contact on Environmental initiatives for service firms. International Journal of Operations \& Production Management 20 (2), pp. 187 203.

[11] Gronroos, C. (1988). Service quality: The six criteria of good service quality. New York: St. John's University.

[12] Hellier, P. K., Geursen, G. M., Carr, R. A., \& Rickard, J. A. (2003). Customer repurchase intention: A general structural equation model. European Journal of Marketing, 37(11/12), pp.1762-1800.

[13] Heskett, James L., W. Earl Sasser, Jr., and Leonard A. Schlesinger (1997), Service Profit Chain New York: Free Press.

[14] Johri, L. M., \& Sahasakmontri, K. (1998). Green marketing of cosmetics and toiletries in Thailand. Journal of Consumer Marketing, 15(3), pp.265-281.

[15] Kholthanasep, G. (2001). A study of Customer Expectations and Perception of Service Quality Delivery by First Class Hotels in Bangkok Metropolitan Area. Master of Business Administration. Bangkok: Assumption University. Photocopied.

[16] Kozikowski, A. (2012). The Interaction between service quality and word-of-mouth on service quality perceptions, satisfaction, loyalty, value and trust. Unpublished Doctoral Dissertation, the Hofstra University.

[17] Low, W.-S., Lee, J.-D., \& Cheng, S.-M. (2013). the link between customer satisfaction and price sensitivity : An investigation of retailing industry in Taiwan. Journal of Retailing and Consumer Services, 20 (1), pp 1-10.

[18] Ok, C., Back, K., \& Shanklin, C. W. (2005). Modeling roles of service recovery strategy: A relationshipfocused view. Journal of Hospitality \& Tourism Research, 29(4), 484-507.

[19] Ostrom A, Iacobucci D. 1995. Consumer trade-offs and the evaluation of services. J. Mark. 59(1). pp. 1728 Reichheld, R., \& Sasser, J., W. E. (1990). Zero defections: Quality comes to service. Harvard Business Review, (68), pp. 105-110. 
[20] Ronald Van Haaften, (2017) Customer satisfaction models form https://www.van-haaften.nl/customersatisfaction/customer-satisfaction-models 4 May, 2017

[21] Rucci, A J., S.P Kirn and R.T. Quinn. (1998) The employee-customer-profit chain at Sears. Harvard Business Review (January-February) pp. 82-97

[22] Shugg, J., Hewitt, H., Cohen, C., Stanford, A., Wood, N., (2007) Travellers' pulse survey form http://revenuemanagement.cc/analysis-consumers-willingness-to-pay-for-green-initiatives-of-the-hotelindustry/ 18 May, 2017

[23] Taylor Steven, Kevin Celuch, Stephen Goodwin, (2004) "The importance of brand equity to customer loyalty", Journal of Product \& Brand Management, Vol. 13 Issue: 4, pp.217-227,

[24] Tinsley, S. (2001). Environmental Management Plans Demystified: A Guide to Implementing Iso 14001. New York: Spon Press

[25] Vilares, M., \& Coelho, P. S. (2003). The employee-customer satisfaction chain in the ECSI model. Portugal European Journal of Marketing, 37(11/12), pp1703-1722.

[26] Woodruff, R. B. (1997). Customer value: The next source of competitive advantage. Journal of the Academy of Marketing Science, 25(1), pp. 139-153.

Citation: Sanhakot Vithayaporn, Rajit Khongharn. "Satisfaction Confirmatory Factor Analysis of Tourists toward Eco-Friendly Hotel Business in Central Region of Thailand". International Journal of Research in Tourism and Hospitality (IJRTH), vol 5, no. 2, 2019, pp. 8-16. doi: http://dx.doi.org/10.20431/24550043.0502002.

Copyright: (C) 2019 Authors. This is an open-access article distributed under the terms of the Creative Commons Attribution License, which permits unrestricted use, distribution, and reproduction in any medium, provided the original author and source are credited. 